\title{
PENYEDIAAN AKSESIBILITAS BAGI WISATAWAN PENYANDANG DISABILITAS OLEH STAKEHOLDER DI KOTAMADYA DENPASAR KECAMATAN DENPASAR SELATAN
}

\author{
Carolina Simanjuntak $^{1}$, Luh Gede Leli Kusuma Dewi ${ }^{2}$, Ni Gusti Ayu Susrami Dewi ${ }^{3}$ \\ ${ }^{1}$ Email: simanjuntak.carolina.cs@gmail.com \\ Program Studi S1 Industri Perjalanan Wisata, Fakultas Pariwisata, Universitas Udayana \\ ${ }^{2}$ Email: leli.kusumadewi@gmail.com \\ Program Studi S1 Industri Perjalanan Wisata, Fakultas Pariwisata, Universitas Udayana \\ 3Email: susramid@gmail.com \\ Program Studi S1 Industri Perjalanan Wisata, Fakultas Pariwisata, Universitas Udayana
}

\begin{abstract}
The purpose of this study is to determine the forms of provision and constraints experienced by stakeholders to provide accessibility for tourists with disabilities in the Denpasar City, South Denpasar District. The informant in this research use purposive sampling method. This research uses descriptive qualitative method, obtained by conducting interview, observation, documentation, and checklist to stakeholder which is divided into three, government, society, and tourism industry. The result of this research is the provision of accessibility for tourists with disabilities by tourism stakeholders in Denpasar City South Denpasar District not yet fully available. The provision of accessibility for tourists with disabilities by tourism stakeholders in Denpasar City, South Denpasar are form of physical accessibility of ram and sliding door while the form of non-physical accessibility are the availability of special services and regulations on the activities of people with disabilities. While the constraints faced by tourism stakeholders in Denpasar City, South Denpasar District in providing accessibility for tourists with disabilities are internal constraints, limited budget and external constraints, regulations that have not specifically regulated the needs of disabled tourists. Suggestion of this research is that among the tourism stakeholder could inisiate, change mindset, and work together in provision accessibility for tourist with disability.
\end{abstract}

Abstrak: Tujuan dari penelitian ini adalah untuk mengetahui bentuk penyediaan serta kendala yang dialami oleh stakeholder dalam penyediaan aksesibilitas bagi wisatawan penyandang disabilitas di Kotamadya Denpasar. Informan dalam penelitian ini menggunakan metode purposive sampling, Penelitian ini menggunakan metode deskriptif kualitatif, yang didapatkan dengan melakukan wawancara mendalam, observasi, dokumentasi, dan checklist kepada stakeholder yang terbagi menjadi tiga yaitu pemerintah, masyarakat, dan industri pariwisata. Hasil dari penelitian ini adalah penyediaan aksesibilitas bagi wisatawan penyandang disabilitas oleh stakeholder pariwisata di Kotamadya Denpasar Kecamatan Denpasar Selatan belum sepenuhnya tersedia. Penyediaan aksesibilitas bagi wisatawan penyandang disabilitas oleh stakeholder di Kotamadya Denpasar Kecamatan Denpasar Selatan adalah bentuk aksesibilitas fisik yaitu ram dan pintu geser, sementara aksesibilitas non fisik adalah tersedianya pelayanan khusus dan peraturan tentang aktivitas wisatawan penyandang disabilitas. Sementara kendala yang dihadapi oleh stakeholder pariwisata di Kotamadya Denpasar, Kabupaten Denpasar Selatan dalam penyediaan aksesibilitas bagi wisatawan penyandang disabilitas adalah kendala internal, keterbatasan anggaran dan kendala eksternal, peraturan yang belum secara khusus mengatur kebutuhan para wisatawan cacat. Saran dari penelitian ini adalah agar antar sesama stakeholder pariwisata dapat berinisiatif, merubah pola pikir, dan berkoordinasi dalam penyediaan akessibilitas bagi wisatawan penyandang disabilitas.

Keywords: accessibility, stakeholder, tourist with disability. 


\section{PENDAHULUAN}

Pariwisata saat ini merupakan bagian dari gaya hidup sebagian besar masyarakat. Berwisata tidak lagi menjadi hal yang awam bagi masyarakat. Tak jarang banyak orang yang berwisata lebih dari satu kali dalam satu tahun. Dalam berbagai variasi wisatawan, perlu diketahui bahwa terdapat wisatawan dengan kebutuhan khusus, dimana wisatawan tersebut memerlukan fasilitas, sarana, dan prasarana yang lebih kompleks dibandingkan dengan wisatawan pada umumnya. Wisatawan berkebutuhan khusus terdiri dari lansia, ibu hamil, anak- anak, dan penyandang disabilitas. Pada kasus ini adalah wisatawan penyandang disabilitas yang juga memiliki keinginan atau motivasi untuk berwisata seperti orang- orang pada umumnya. Penyandang disabilitas memiliki strata yang setara dalam segala aspek kehidupan seperti masyarakat pada umumnya termasuk dalam berwisata.

Merujuk pada tema World Tourism Day 2016 yang bertajuk Tourism For All, United Nations World Tourism Organization atau yang lebih sering disebut UNWTO ingin agar dunia kepariwisataan dapat di nikmati oleh siapa saja tanpa terkecuali. Komitmen UNWTO dalam tema Tourism For All dilatarbelakangi oleh Global Code Ethics Of Tourism - Article 7, dimana akses untuk menemukan dan menikmati sumber daya merupakan suatu hak bagi segala penduduk dunia. Selain itu pada Global Code Ethics Of Tourism - Article 7 poin 4, tertulis bahwa keluarga, pemuda, pelajar, lansia, dan orangorang penyandang disabilitas, harus di dukung dan di fasilitasi dalam berwisata. Tahun 2011, WHO mengestimasi setidaknya $15 \%$ dari populasi di dunia mengalami disabilitas (Sumber: World Report On Disabilitiy: 2011). Itu berarti 1 miliar orang di dunia hidup dengan disabilitas.

Memfasilitasi penyandang disabilitas dalam berwisata tidak hanya semata- mata untuk memenuhi hak mereka untuk beriwisata, tetapi juga sebagai peluang bisnis di industri pariwisata. Perubahan pola pikir dan perubahan regulasi penyediaan jasa pariwisata diperlukan agar dapat memenuhi permintaan pasar tersebut. Peningkatan aksesbilitas dan layanan jasa bagi penyandang disabilitas serta merta akan meningkatkan kualitas dari produk pariwisata dan juga meningkatkan perilaku kompetitif antar industri pariwisata. Dengan terus meningkatnya kunjungan wisatawan, peningkatan kualitas pelayanan dan infrastruktur juga harus mengimbangi fenomena tersebut. Bali sebagai destinasi senior di Indonesia, seharusnya sudah dapat memfasilitasi orang- orang dengan berkebutuhan khusus dibandingkan dengan provinsi- provinsi lain yang masih mengembangkan potensi pariwisatanya. Untuk memenuhi kebutuhan dan permintaan pasar pada wisatawan penyandang disabilitas, maka harus ada kerja sama diantara stakeholder pariwisata.

Visi pariwisata yang disajikan dalam Accessible Tourism for All 2005 yang diperbaharui pada 2013 oleh UNWTO, mendorong diluncurkannya kolaborasi kerja sama di antara berbagai pemangku kepentingan di sektor pariwisata, sehingga masyarakat berkebutuhan khusus dapat menikmati dengan mandiri produk wisata, layanan, dan sumber daya yang dirancang bagi mereka.

Sebagian besar, pemangku kepentingan yakni pemerintah dan pihak swasta atau investor serta masyarakat sampai saat ini kurang mempertimbangkan penyandang disabilitas sebagai calon wisatawan yang potensional. Pasalnya masih banyak destinasi pariwisata di Bali secara khusus belum memiliki fasilitas pendukung bagi penyandang disabilitas. Tak hanya kurangnya fasilitas pendukung, tetapi kurangnya informasi yang lengkap dan aksesibilitas yang tidak memadai menjadi alasan bagi penyandang disabilitas untuk tidak melakukan aktivitas berwisata di Bali. Dalam hal ini pemerintah mempunyai peran penting dalam terwujudnya pariwisata yang ramah bagi siapa saja tanpa terkecuali penyandang disabilitas. Dengan membuat regulasi yang pro terhadap penyandang disabilitas dan merangkul para stakeholder untuk bersama- sama merancang pariwisata yang ramah bagi penyandang disabilitas, maka hal tersebut dapat terwujud. Peluang inilah yang harus dilihat oleh pemerintah sehingga tidak hanya meningkatkan kualitas tetapi juga meningkatkan pendapatan bagi destinasi itu sendiri.

Burn dan Holden dalam Pitana dan Gayatri (2005) menyebutkan bahwa sektor pariwisata ditopang oleh aktor atau stakeholder yang terdiri dari tiga pilar utama yaitu pemerintah, masyarakat, dan swasta. 
Ketiganya harus dapat bekerja sama untuk mencapai suatu tujuan. Hubungan yang harmonis diantara ketiganya akan memberikan dampak yang sangat baik bagi penyedian pelayanan untuk wisatawan penyandang disabilitas. Pemerintah selayaknya dapat membuat regulasi yang pro terhadap kebutuhan berwisata wisatawan penyandang disabilitas. Sedangkan pihak swasta dapat peka terhadap kebutuhan berwisata wisatawan penyandang disabilitas dan dapat melihat hal itu sebagai peluang bisnis. Dan masyarakat selayaknya dapat memiliki pengetahuan atau pola pikir mengenai kebutuhan berwisata wisatawan penyandang disabilitas.

Untuk membuat suatu destinasi wisata yang ramah bagi penyandang disabilitas dibutuhkan upaya- upaya, tidak hanya dari satu pihak tetapi dari berbagai pihak, dalam hal ini adalah stakeholder pariwisata. Upayaupaya tersebut harus berkesinambungan satu sama lain agar dapat mencapai suatu tujuan sehingga Bali menjadi destinasi yang ramah bagi siapa saja termasuk wisatawan penyandang disabilitas. Karena berwisata merupakan hak semua orang tanpa terkecuali penyandang disabilitas, dimana mereka juga ingin merasakan pengalaman berwisata dengan orang- orang pada umumnya, sehingga saat berwisata penyandang disabilitas tidak hanya berdiam diri di akomodasi karena objek wisata di Bali tidak aksesibel.

Salah satu wilayah Bali yang terkenal akan pariwisata adalah Kotamadya Denpasar. Tidak hanya terkenal dengan pariwisatanya, Kotamadya Denpasar juga merupakan Ibukota Provinsi Bali. Kotamadya Denpasar terdiri dari empat wilayah yaitu Denpasar Timur, Denpasar Barat, Denpasar Utara, dan Denpasar Selatan. Keunikan lain dari Kotamadya Denpasar adalah Kotamadya Denpasar terpilih sebagai salah satu Pilot Project Kota Ramah Lansia oleh lembaga Survey Meter dan Center for Ageing Studies, Universitas Indonesia. Dimana aksesibilitas dan fasilitas bagi lansia atau lanjut usia sama dengan aksesibilitas dan fasilitas bagi penyandang disabilitas. Kriteria Pilot Project Kota Ramah Lansia yang ditetapkan oleh WHO (World Health Organization) memiliki 8 dimensi yakni gedung dan ruang terbuka, transportasi, perumahan, partisipasi sosial, keterlibatan sosial, partisipasi sipil dan pekerjaan, komunikasi dan informasi, dukungan masyarakat dan pelayanan kesehatan. Kawasan pariwisata yang banyak dikunjungi di Kotamadya Denpasar adalah Kecamatan Denpasar Selatan. Pada Kecamatan Denpasar Selatan terdapat Monumen Bajra Sandhi dan kawasan pariwisata Sanur. Berdasarkan obeservasi peneliti dalam situs Trip Advisor, kawasan Sanur di anjurkan oleh wisatawan sebagai kawasan yang cukup ramah bagi wisatawan penyandang disabilitas dibandingkan dengan kawasan pariwisata lain di Bali seperti Kuta, Jimbaran, Seminyak dan sebagainya. Pada forum diskusi di situs Trip Advisor, Sanur disarankan oleh wisatawan karena akses menuju pantai cukup mudah dan jarak antara trotoar menuju pantai tidak terlalu tinggi, sehingga wisatawan dapat menikmati alam Sanur tanpa hambatan berarti.

Berdasarkan latar belakang tersebut, maka diketahui bentuk penyediaan aksesibilitas bagi wisatawan penyandang disabilitas oleh stakeholder dan kendala yang dihadapi oleh stakeholder di Kotamadya Denpasar Kecamatan Denpasar Selatan.

\section{METODE}

Lokasi pada penulisan jurnal ini dilakukan di Kotamadya Denpasar Kecamatan Denpasar Selatan atas dasar Kotamadya Denpasar terpilih sebagai salah satu Pilot Project Kota Ramah Lansia oleh lembaga Survey Meter dan Center for Ageing Studies, Universitas Indonesia. Dimana aksesibilitas dan fasilitas bagi lansia atau lanjut usia sama dengan aksesibilitas dan fasilitas bagi penyandang disabilitas. Kriteria Pilot Project Kota Ramah Lansia yang ditetapkan oleh WHO (World Health Organization) memiliki 8 dimensi yakni gedung dan ruang terbuka, transportasi, perumahan, partisipasi sosial, keterlibatan sosial, partisipasi sipil dan pekerjaan, komunikasi dan informasi, dukungan masyarakat dan pelayanan kesehatan.

Sedangkan Kecamatan Denpasar Selatan dipilih karena kawasan pariwisata yang banyak dikunjungi di Kotamadya Denpasar adalah Kecamatan Denpasar Selatan. Berdasarkan obeservasi peneliti dalam situs Trip Advisor, kawasan Sanur di anjurkan oleh wisatawan sebagai kawasan yang cukup ramah bagi wisatawan penyandang disabilitas dibandingkan dengan kawasan pariwisata lain 
di Bali seperti Kuta, Jimbaran, Seminyak dan sebagainya. Pada forum diskusi di situs Trip Advisor, Sanur disarankan oleh wisatawan karena akses menuju pantai cukup mudah dan jarak antara trotoar menuju pantai tidak terlalu tinggi, sehingga wisatawan dapat menikmati alam Sanur tanpa hambatan berarti.

Adapun variabel yang diteliti dalam penelitian ini adalah aksesibilitas dan kendala, dimana aksesibilitas terbagi menjadi aksesibilitas fisik dan aksesibilitas non fisik. Sedangkan kendala terbagi menjadi kendala internal dan kendala eksternal. Indikator yang digunakan dalam aksesibilitas fisik yaitu, 1) tersedianya pintu, tangga, dan lift khusus, 2) tersedianya tempat parkir, 3) tersedianya toilet, 4) tersedianya telepon, 5) tersedianya peringatan darurat, 6) tersedianya rambu, 7) tersedianya trotoar khusus penyandang disabilitas, 8) tersedianya ram, 9) tersedianya tempat duduk, 10) tersedianya paket khusus penyandang disabilitas. indikator yang digunakan pada aksesibilitas non fisik yaitu, 1) Tersedianya informasi yang andal, 2) Tersedianya peraturan dan regulasi terhadap aktivitas berwisata penyandang disabilitas, 3 ) Tersedianya pelayanan khusus, 4) Etika membantu penyandang disabilitas secara umum, 5) Sumber daya manusia yang kapabel dalam menangani wisatawan penyandang disabilitas.

Indikator yang digunakan dalam kendala internal adalah 1) Modal atau anggaran yang terbatas, 2) Sumber daya manusia yang belum kapabel dalam menangani wisatawan peyandang disabilitas. Sedangkan indikator yang digunakan dalam kendala eksternal adalah 1) Peraturan yang belum secara spesifik mengatur mengenai kebutuhan wisatawan penyandang disabilitas, 2) Permintaan dari wisatawan penyandang disabilitas yang rendah, 3) Peraturan dan sanksi yang belum tegas untuk pengupayaan penyediaan aksesibilitas dan fasilitas bagi penyadang disabilitas.

Teknik pengumpulan data yang digunakan dalam penelitian ini yaitu: 1) Observasi, dengan melakukan pengamatan secara langsung di Monumen Bajra Sandhi, Kawasan Sanur, Villa G at Ellora, Rumah Sanur, Bali Access Travel, Smailing Tour, Bali One Care, HPI Bali, PHRI Bali, ASITA Bali, Yayasan Pembangunan Sanur, dan Dinas Pariwisata Kota Denpasar guna mendapatkan gambaran mengenai lokasi penelitian. 2) Wawancara, dengan melakukan tanya jawab secara langsung kepada Sekretaris Dinas Pariwisata Kota Denpasar, Human Resource Manager Bali Access Travel, Kepala Divisi operasional Smailing Tour, pemilik Villa G at Ellora, Humas ASITA Bali, Direktur Eksekutif PHRI Bali, perwakilan dari Himpunan Pramuwisata Indonesia Bali, sekretaris Yayasan Pembangunan Sanur, founder Rumah Sanur, dan founder Bali One Care. 3) Studi kepustakaan yaitu, mencari informasi dengan berbagai buku atau literatur - literatur yang berkaitan dengan penelitian ini dan dapat mendukung kelengkapan dari penelitian ini, dan 4) Dokumentasi, dengan mengumpukan data dari arsip-arsip dan foto-foto kegiatan terkait dengan penelitian ini.

Teknik penentuan informan dilakukan secara purposive sampling menggunakan informan pangkal dan informan kunci. Adapun yang menjadi informan pangkal pada penelitian ini adalah Bapak Drs. I Nyoman Nada, M.Si, selaku Sekretaris Dinas Pariwisata Kota Denpasar, dan yang menjadi informan kunci adalah Bapak Purwa selaku Direktur Eksekutif PHRI Bali, Bapak Puji selaku HPI Bali, Bapak Yoga selaku Humas ASITA, Bapak Marshall selaku pemilik Villa $\mathrm{G}$ at Ellora, Bapak Romi selaku pemilik Bali One Care, Bapak Bob selaku founder Rumah Sanur, Bapak Dewa selaku divisi informasi Monumen Bajra Sandhi, Ibu Dewi selaku human resource manager Bali Access Travel, Bapak I Putu Suwanta selaku Sekretaris Yayasan Pembangunan Sanur, Bapak Andre selaku divisi operator Smailing Tour, dan Mr. Anonim kewarganegaraan Prancis, selaku wisatawan peyandang disabilitas di Pantai Sindhu. Teknik analisis data yang dilakukan pada penelitian ini adalah analisis deskriptif kualitatif.

\section{HASIL}

\section{Gambaran Umum}

Stakeholder pariwisata mencakup tiga pilar yaitu pemerintah, masyarakat, dan pihak swasta. Pemerintah diwakili oleh Dinas Pariwisata Kota Denpasar, masyarakat diwakili oleh PHRI Bali, HPI Bali, ASITA Bali, dan pihak swasta diwakili oleh Bali One Care, Rumah Sanur, Bali Access Travel, Smailing Tour, Villa $G$ at Ellora, Monumen Bajra Sandhi, dan Kawasan Sanur. 
Dinas Pariwisata merupakan dinas teknis yang menangani bidang kepariwisataan khususnya di Kotamadya Denpasar. Dinas Pariwisata Kota Denpasar memiliki visi yaitu "Terwujudnya Kota Denpasar sebagai Kota Pariwisata Budaya yang berkelanjutan dilandasi Tri Hita Karana”. Misi dari Dinas Pariwisata Kota Denpasar adalah Mengembangkan Daya Tarik Wisata yang mengedepankan kearifan lokal, Membangun Sarana dan Prasarana dalam keselarasan dan keharmonisan lingkungan, Mewujudkan kualitas pelayanan yang baik kepada masyarakat, dan Mengoptimalkan sarana informasi dan menyelenggarakan promosi yang lebih berkualitas.

ASITA adalah Asosiasi Perusahaan Perjalanan Wisata Indonesia dan pertama kali berdiri di Jakarta pada tanggal 7 Januari 1971. ASITA memiliki 31 Dewan Pimpinan Daerah (DPD) yang tersebar di seluruh Indonesia dan salah satunya terdapat di Bali yang didirikan pada tahun 1974. ASITA Bali mempunyai divisi-divisi yang memiliki pangsa pasarnya masing-masing.

Perhimpunan Hotel dan Restoran Indonesia atau yang lebih sering disebut dengan PHRI adalah lembaga yang menjadi payung bagi anggotanya yang bergerak di bidang perhotelan, restoran, jasa boga serta lembaga pendidikan pariwisata. Fungsi dari PHRI ini adalah untuk mengembangkan potensi anggota, bimbingan, konsultasi, penggalangan kerjasama, memberikan perlindungan, promosi dalam dan luar negeri, serta penelitian, dan perencanaan pengembangan usaha.

HPI merupakan singkatan dari Himpunan Pramuwisata Indonesia. HPI adalah lembaga atau organisasi yang menghimpun pramuwisata di Indonesia. Dahulu HPI bernama HDWI atau Himpunan Duta Wisata Indonesia dan pada tahun 1989 berubah nama menjadi HPI. Rapat Kerja Nasional HPI pertama tahun 1989 melahirkan logo HPI yaitu Burung Cendrawasih yang diajukan oleh delegasi HPI Bali.

Yayasan Pembangunan Sanur dibentuk pada tahun 1965. Yayasan ini terbentuk dilatarbelakangi oleh kekhawatiran masyarakat Sanur akan besarnya gempuran industri pariwisata yang mengakibatkan tergerusnya adat budaya Bali khususnya daerah Sanur. Yayasan Pembangunan Sanur didirikan agar dapat mempertahankan keberadaan masyarakat asli Sanur tanpa tergusur dari tanah kelahiran sendiri.

Bali One Care adalah perusahaan penyediaan alat bantu bagi orang- orang dengan berkebutuhan khusus seperti lansia, ibu hamil, balita, dan penyandang disabilitas. Adalah Bapak Putu Romi Adi Karsika atau sering disebut dengan Bapak Romi, yang membentuk Bali One Care ini, dimana latar belakang beliau adalah sebagai perawat yang sudah berpengalaman selama 15 tahun di Bali dan internasional.

Villa G merupakan akomodasi yang cocok bagi keluarga dan orang- orang dengan kebutuhan khusus. Pemilik Villa G adalah Mr. Marshall yang berasal dari Australia. Villa G memiliki akses yang rata tanpa tangga dan sangat ramah bagi pengguna kursi roda.

Rumah Sanur adalah sebuah wadah bagi orang- orang untuk saling berkoneksi, berkolaborasi, dan bersenang- senang. Di dalam Rumah Sanur terdapat bar, coffee shop, coworking space, restoran, café, dan concept store. Pada bulan Desember 2017 Rumah Sanur melakukan revitalisasi gedung agar dapat aksesibel bagi penyandang disabilitas.

Monumen Bajra Sandhi merupakan Monumen Perjuangan Rakyat Bali dimana dibangun untuk memberi hormat kepada para pahlawan. Monumen ini dikenal dengan nama "Bajra Sandhi" karena bentuknya menyerupai bajra atau genta yang digunakan oleh para Pendeta Hindu dalam mengucapkan Weda pada saat upacara keagamaan.

Kawasan Pariwisata Sanur terletak di wilayah Kotamadya Denpasar tepatnya di Kecamatan Denpasar Selatan. Pada kawasan Pariwisata Sanur terdapat beberapa pantai yang memiliki garis pantai yang sama seperti Pantai Sanur, Pantai Sindu, Pantai Karang, Pantai Matahari Terbit, dan lain- lain.

Smailing Tour and Travel didirikan di Jakarta tanggal 10 Juli 1976. Smailing Tour memiliki beberapa kantor cabang di beberapa tempat strategis dan tersebar di beberapa kota di Indonesia, salah satunya adalah Kantor Cabang Smailing Tour and Travel Bali yang baru dibuka pada tahun 1988 .

Bali Access Travel merupakan travel khusus bagi wisatawan berkebutuhan khusus. Bali Access Travel sudah berdiri sejak tahun 2006 atas kerja sama yang dipelopori oleh seorang paramedis asal Inggris yang dahulu 
pernah bekerja di BIMC Hospital dan seorang berkewarganegaraan Australia. Bali Access Travel adalah travel yang pertama yang menyediakan jasa perjalanan bagi wisatawan penyandang disabilitas.

\section{Bentuk Penyediaan Aksesibilitas Fisik}

Penyediaan aksesibilitas fisik bagi wisatawan penyandang disabilitas oleh stakeholder dalam hal ini adalah pemerintah, masyarakat, dan industri pariwisata di Kotamadya Denpasar Kecamatan Denpasar Selatan sebagai berikut.

Tabel 1 Bentuk Penyediaan Aksesibilitas Fisik Oleh Pemerintah

\begin{tabular}{|c|c|c|}
\hline Sub variabel & Indikator & $\begin{array}{l}\text { Dinas } \\
\text { Pariwisata } \\
\text { Kota } \\
\text { Denpasar }\end{array}$ \\
\hline \multirow{9}{*}{$\begin{array}{l}\text { Aksesibilitas } \\
\text { Fisik }\end{array}$} & $\begin{array}{l}\text { 1. Tersedianya } \\
\text { pintu, tangga, } \\
\text { dan lift khusus }\end{array}$ & $\begin{array}{l}\text { Tidak } \\
\text { tersedia }\end{array}$ \\
\hline & $\begin{array}{l}\text { 2. Tersedianya } \\
\text { tempat parkir }\end{array}$ & $\begin{array}{l}\text { Tidak } \\
\text { tersedia }\end{array}$ \\
\hline & $\begin{array}{l}\text { 3. Tersedianya } \\
\text { toilet }\end{array}$ & Tersedia \\
\hline & $\begin{array}{l}\text { 4. Tersedianya } \\
\text { telepon }\end{array}$ & $\begin{array}{l}\text { Tidak } \\
\text { tersedia }\end{array}$ \\
\hline & $\begin{array}{l}\text { 5. Tersedianya } \\
\text { peringatan } \\
\text { darurat }\end{array}$ & $\begin{array}{l}\text { Tidak } \\
\text { tersedia }\end{array}$ \\
\hline & $\begin{array}{l}\text { 6. Tersedianya } \\
\text { rambu }\end{array}$ & $\begin{array}{l}\text { Tidak } \\
\text { tersedia }\end{array}$ \\
\hline & $\begin{array}{l}\text { 7. Tersedianya } \\
\text { trotoar khusus } \\
\text { penyandang } \\
\text { disabilitas }\end{array}$ & $\begin{array}{l}\text { Tidak } \\
\text { tersedia }\end{array}$ \\
\hline & $\begin{array}{l}\text { 8. Tersedianya } \\
\text { ram }\end{array}$ & $\begin{array}{l}\text { Tidak } \\
\text { tersedia }\end{array}$ \\
\hline & $\begin{array}{l}\text { 9. Tersedianya } \\
\text { tempat duduk }\end{array}$ & $\begin{array}{l}\text { Tidak } \\
\text { tersedia }\end{array}$ \\
\hline \multicolumn{3}{|c|}{ Sumber: Hasil Olahan Peneliti : (2018) } \\
\hline \multicolumn{3}{|c|}{$\begin{array}{l}\text { Bentuk aksesibilitas fisik oleh pemerintah } \\
\text { pada terdapat } 9 \text { indikator yakni terdapat pintu, } \\
\text { tangga, lift khusus, tersedia tempat parkir, } \\
\text { toilet khusus, telepon, peringatan darurat, } \\
\text { rambu, trotoar khusus, ram, dan tempat duduk. } \\
\text { Dalam hal ini, penyediaan aksesibilitas secara } \\
\text { fisik bagi wisatawan penyandang disabilitas } \\
\text { dalam sudut pandang Dinas Pariwisata Kota } \\
\text { Denpasar belum memadai. Dari semua } \\
\text { indikator akesesibilitas fisik yakni pintu, }\end{array}$} \\
\hline
\end{tabular}

tangga, lift khusus, tempat parkir, toilet, telepon, peringatan darurat, rambu, trotoar khusus, ram, dan tempat duduk, hanya toilet saja yang baru tersedia.

Bentuk aksesibilitas fisik oleh masyarakat yang diwakili oleh HPI Bali, ASITA Bali, PHRI Bali, dan Yayasan Pembangunan Sanur seperti pintu, tangga, lift khusus, tersedia tempat parkir, toilet khusus, telepon, peringatan darurat, rambu, trotoar khusus, ram, dan tempat duduk. Dari semua indikator tersebut, dan menurut sudut pandang masyarakat dalam hal ini HPI Bali, ASITA Bali, PHRI Bali, dan Yayasan Pembangunan Sanur sampai saat ini belum menyediakan aksesibilitas fisik bagi wisatawan penyandang disabilitas di objek- objek wisata di Kotamadaya Denpasar Kecamatan Denpasar Selatan. Aksesibilitas dalam bentuk fisik tersebut hanya disediakan secara umum dan tidak khusus bagi wisatawan penyandang disabilitas.

Tabel 2. Indikator Bentuk Penyediaan Aksesibilitas Fisik Oleh Industri Pariwisata

\begin{tabular}{|c|c|}
\hline Sub variabel & Indikator \\
\hline \multirow{10}{*}{$\begin{array}{l}\text { Aksesibilitas } \\
\text { Fisik }\end{array}$} & $\begin{array}{l}\text { 1. Tersedianya pintu, tangga, } \\
\text { dan lift khusus }\end{array}$ \\
\hline & 2. Tersedianya tempat parkir \\
\hline & 3. Tersedianya toilet \\
\hline & 4. Tersedianya telepon \\
\hline & $\begin{array}{l}\text { 5. Tersedianya peringatan } \\
\text { darurat }\end{array}$ \\
\hline & 6. Tersedianya rambu \\
\hline & $\begin{array}{l}\text { 7. Tersedianya trotoar khusus } \\
\text { penyandang disabilitas }\end{array}$ \\
\hline & 8. Tersedianya ram \\
\hline & 9. Tersedianya tempat duduk \\
\hline & $\begin{array}{l}\text { 10. Tersedianya paket khusus } \\
\text { penyandang disabilitas }\end{array}$ \\
\hline
\end{tabular}

Sumber: Hasil Olahan Peneliti : (2018)

Tabel diatas merupakan indikator dalam penyediaan aksesibilitas fisik oleh industri pariwisata yakni Villa $G$ at Ellora, Rumah Sanur, Bali One Care, Museum Bajra Sandhi, Kawasan Sanur, Bali Access Travel, dan Smailing Tour. Hanya saja pada indikator nomor 10 berlaku bagi Bali Access Travel dan Smailing Tour. Berkaitan dengan aksesibilitas fisik yang disediakan oleh industri pariwisata di Kotamadya Denpasar Kecamatan Denpasar 
Selatan, ketersediaan toilet, rambu, dan ram sudah dimiliki oleh beberapa industri yakni Rumah Sanur, Kawasan Sanur (Pantai Karang), dan Villa $G$ at Ellora. Untuk ketersediaan tempat parkir, hanya dimiliki oleh Rumah Sanur, dan paket khusus penyandang disabilitas hanya disediakan oleh Bali Access Travel.

\section{Bentuk Penyediaan Aksesibilitas Non Fisik}

Aksesibilitas non fisik merupakan kemudahan dan kenyamanan yang disediakan untuk penyandang disabilitas guna mewujudkan kesamaan kesempatan dalam segala aspek kehidupan dan penghidupan. Berikut adalah bentuk penyediaan aksesibilitas non fisik oleh stakeholder bagi wisatawan penyandang disabilitas di Kotamadya Denpasar Kecamatan Denpasar Selatan.

Tabel 3 Indikator Bentuk Penyediaan Aksesibilitas Non Fisik oleh Pemerintah

\begin{tabular}{cl}
\hline Sub variabel & Indikator \\
\hline & $\begin{array}{l}\text { 1. Tersedianya informasi yang } \\
\text { andal }\end{array}$ \\
\cline { 2 - 2 } 2. Tersedianya peraturan dan \\
regulasi terhadap aktivitas \\
Nonsesibilitas & $\begin{array}{l}\text { berwisata penyandang } \\
\text { disabilitas }\end{array}$ \\
\cline { 2 - 2 } & $\begin{array}{l}\text { 3. Tersedianya pelayanan } \\
\text { khusus }\end{array}$ \\
\hline
\end{tabular}

Sumber: Hasil Olahan Peneliti : (2018)

Bentuk aksesibilitas non fisik oleh Dinas Pariwisata Kota Denpasar, belum memadai karena sampai saat ini belum tersedia informasi yang andal yaitu informasi dalam bentuk huruf Braile maupun audiovisual dan pelayanan khusus bagi wisatawan penyandang disabilitas. Bentuk aksesibilitas non fisik yang baru tesedia sampai saat ini adalah peraturan dan regulasi terhadap aktivitas berwisata penyandang disabilitas. Peraturan dan regulasi yang sudah ada merupakan turunan dari peraturan dan regulasi dari Kementrian Pariwisata.

Dalam hal ketersediaan informasi yang andal, HPI, PHRI, dan ASITA belum menyediakan informasi yang andal dalam artian informasi berbentuk huruf Braile maupun bentuk audiovisual. Begitu juga dengan penyediaan pelayanan khusus yang belum disediakan oleh HPI, PHRI, ASITA.
Sedangkan HPI, PHRI, ASITA menyatakan bahwa sudah terdapat peraturan dan regulasi yang mengatur mengenai aktivitas wisatawan penyandang disabilitas.

Tabel 4. Indikator Bentuk Penyediaan Aksesibilitas Non Fisik Oleh Industri Pariwisata (Akomodasi, Restoran dan café, Industri pendukung, Objek Wisata)

\begin{tabular}{cl}
\hline Sub variabel & Indikator \\
\hline & $\begin{array}{l}\text { 1. Tersedianya informasi yang } \\
\text { andal }\end{array}$ \\
\cline { 2 - 2 } Aksesibilitas & $\begin{array}{l}\text { 2. Tersedianya pelayanan khusus } \\
\text { Non fisik } \\
\text { (SDM yang kapabel dalam } \\
\text { melayani penyandang } \\
\text { disabilitas) }\end{array}$ \\
\hline Sumber: Hasil Olahan Peneliti : (2018)
\end{tabular}

Bentuk penyediaan aksesibilitas non fisik yakni tersedianya informasi yang andal dan tersedianya pelayanan khusus. Pada Villa G at Ellora, Bali One Care, Rumah Sanur, Monumen Bajra Sandhi, dan Kawasan Pariwisata Sanur belum memiliki atau menyediakan informasi yang andal. Sedangkan pelayanan khusus dalam melayani penyandang disabilitas hanya Villa $\mathrm{G}$ at Ellora dan Bali One Care saja yang menyediakan sedangakan Rumah Sanur, Monumen Bajra Sandhi, dan Kawasan Pariwisata Sanur belum menyediakan pelayanan khusus bagi wisatawan penyandang disabilitas.

Tabel 5. Indikator Bentuk Penyediaan Aksesibilitas Non Fisik Oleh Industri Pariwisata (Biro Perjalanan Wisata)

\begin{tabular}{ll}
\hline Sub variabel & Indikator \\
\hline & $\begin{array}{l}\text { 1. Etika membantu penyandang } \\
\text { disabilitas secara umum }\end{array}$ \\
\cline { 2 - 2 } $\begin{array}{l}\text { 2. Sumber daya manusia yang } \\
\text { kapabel dalam menangani }\end{array}$ \\
Aksesibilitas & $\begin{array}{l}\text { wisatawan penyandang } \\
\text { disabilitas }\end{array}$ \\
\cline { 2 - 2 } Non fisik & 3. Tersedianya informasi \\
\cline { 2 - 2 } & $\begin{array}{l}\text { 4. Tersedianya pelayanan } \\
\text { khusus }\end{array}$ \\
\hline
\end{tabular}

Sumber: Hasil Olahan Peneliti : (2018)

Etika membantu wisatawan penyandang disabilitas secara umum, sumber daya manusia yang kapabel dalam menangani wisatawan penyandang disabilitas, serta tersedianya 
pelayanan khusus sudah ada dan diterapkan oleh Bali Access Travel walaupun Smailing Tour belum. Penyediaan informasi yang andal oleh pihak Smailing Tour dan Bali Access Travel belum tersedia. Aksesibilitas non fisik berupa etika membantu penyandang disabilitas secara umum, sumber daya manusia yang kapabel dalam menangani wisatawan penyandang disabilitas, pelayanan khusus, pihak Smailing Tour belum menyediakan pelayanan tersebut kepada wisatawan penyandang disabilitas.

\section{Kendala Internal Penyediaan Aksesibilitas}

Untuk mencapai suatu tujuan, biasanya individu atau organisasi atau kelompok secara langsung mengalami adanya keterbatasan dalam kegiatan operasionalnya sebagai suatu sumber daya yang terbatas atau dapat disebut dengan kendala. Kendala internal merupakan kendala yang bersaal dari dalam perusahaan. Berikut adalah indikator kendala internal yang dihadapi oleh stakeholder.

Tabel 6 Indikator Kendala Internal yang Dihadapi oleh Stakeholder

\begin{tabular}{cl}
\hline Sub variabel & Indikator \\
\hline \multirow{3}{*}{ Internal } & $\begin{array}{l}\text { 1. Modal atau anggaran yang } \\
\text { terbatas }\end{array}$ \\
\cline { 2 - 2 } & $\begin{array}{l}\text { 2. Sumber daya manusia yang } \\
\text { belum kapabel dalam menangani } \\
\text { wisatawan peyandang disabilitas }\end{array}$ \\
\hline Sumber: Hasil Olahan Peneliti : $(2018)$
\end{tabular}

Sumber: Hasil Olahan Peneliti : (2018)

Mengenai kendala internal yang dihadapi oleh Dinas Pariwisata Kota Denpasar, sumber daya manusia yang belum kapabel dalam menangani wisatawan penyandang disabilitas menjadi kendala internal bagi pihak Dinas Pariwisata Kota Denpasar. Tetapi pada indikator modal atau anggaran yang terbatas tidak menjadi kendala bagi Dinas Pariwisata Kota Denpasar.

HPI Bali, ASITA Bali, dan PHRI Bali beranggapan bahwa modal atau anggaran yang terbatas bukanlah sebuah kendala internal dalam penyediaan aksesibilitas bagi wisatawan penyandang disabilitas. Selanjutnya sumber daya manusia yang belum kapabel dalam menangani wisatawan penyandang disabilitas dalam sudut pandang HPI dan PHRI tidak menjadi kendala dalam penyediaan aksesibilitas bagi wisatawan penyandang disabilitas. Sedangkan ASITA Bali menyatakan bahwa sumber manusia yang belum kapabel akan menjadi kendala dalam berkomunikasi dengan wisatawan penyandang disabilitas.

Berdasarkan sudut pandang indsutri pariwisata, kendala internal yang dihadapi adalah modal dan anggaran menjadi kendala bagi Villa $G$ at Ellora, Bali One Care dan Rumah Sanur. Sedangkan sumber daya manusia yang belum kapabel dalam menangani wisatawan penyandang disabilitas, tidak menjadi kendala bagi Villa $G$ at Ellora, Bali One Care, dan Rumah Sanur.

Bagi Monumen Bajra Sandhi dan Kawasan Pariwisata Sanur, modal atau anggaran menjadi kendala dalam penyediaan aksesibilitas bagi wisatawan penyandang disabilitas. Selain itu menurut Monumen Bajra Sandhi dan Kawasan Pariwisata Sanur sumber daya manusia yang belum kapabel dalam menangani wisatawan penyandang disabilitas menjadi kendala dalam penyediaan aksesibilitas bagi wisatawan penyandang disabilitas.

Bagi Bali Access Travel modal dapat dikatakan menjadi kendala. Sedangkan bagi Smailing Tour modal tidak menjadi masalah internal. Sumber daya manusia yang belum kapabel dalam menangani wisatawan penyandang disabilitas bukanlah menjadi suatu kendala bagi Bali Access Travel dan Smailing Tour.

Kendala Eksternal Penyediaan Aksesibilitas Kendala eksternal (external constraint) adalah faktor-faktor yang membatasi perusahaan yang berasal dari luar perusahaan, misalnya permintaan pasar yang minim, kurangnya minat atau inisiatif dari beberapa pihak dalam mengupayakan fasilitas kepada penyandang disabilitas. Berikut adalah kendala eksternal yang dihadapi oleh stakeholder dalam penyediaan aksesibilitas bagi wisatawan penyandang disabilitas di Kotamadya Denpasar Kecamatan Denpasar Selatan. 
Tabel 7 Indikator Kendala Eksternal oleh Stakeholder

\begin{tabular}{ll}
\hline $\begin{array}{l}\text { Sub } \\
\text { variabel }\end{array}$ & Indikator \\
\hline & $\begin{array}{l}\text { 1. Peraturan yang belum secara } \\
\text { spesifik mengatur mengenai } \\
\text { kebutuhan wisatawan penyandang } \\
\text { disabilitas }\end{array}$ \\
\cline { 2 - 2 } $\begin{array}{l}\text { Kendala } \\
\text { Eksternal }\end{array}$ & \begin{tabular}{l} 
2. Permintaan yang rendah \\
\cline { 2 - 2 }
\end{tabular} \\
$\begin{array}{l}\text { 3. Peraturan yang belum tegas untuk } \\
\text { penguanan penyediaan fasilitas } \\
\text { bagi penyadang disabilitas }\end{array}$ \\
\hline
\end{tabular}

Sumber: Hasil Olahan Peneliti : (2018)

Menurut Dinas Pariwisata Kota Denpasar peraturan sudah ada yang mengatur mengenai kebutuhan wisatawan penyandang disabilitas. Lalu menurut Bapak Drs. I Nyoman Nada, M.Si permintaan yang rendah juga menjadi alasan aksesibilitas dan fasilitas bagi wisatawan penyandang disabilitas masih sangat minim.

Peraturan yang belum secara spesifik mengatur mengenai kebutuhan wisatawan penyandang disabilitas dialami oleh pihak HPI dan ASITA, sedangkan PHRI sudah mempunyai regulasi yang tertulis. Lalu pada indikator permintaan wisatawan penyandang disabilitas yang rendah dan peraturan dan sanksi yang belum tegas untuk pengupayaan penyediaan aksesibilitas dan fasilitas bagi wisatawan penyandang disabilitas, HPI Bali, PHRI Bali, dan ASITA Bali menyatakan bahwa hal terebut menjadi kendala yang mereka hadapi.

Kendala eksternal dalam penyediaan aksesibilitas bagi wisatawan penyandang disabilitas yang dialami oleh Villa $\mathrm{G}$ at Ellora, Rumah Sanur, dan Bali One Care mengenai peraturan yang belum secara spesifik mengatur mengenai kebutuhan wisatawan penyandang disabilitas dan peraturan dan sanksi yang belum tegas untuk pengupayaan penyediaan aksesibilitas dan fasilitas bagi wisatawan penyandang disabilitas. Sedangkan untuk permintaan wisatawan penyandang disabilitas yang rendah bagi Villa $G$ at Ellora, Bali One Care, dan Rumah Sanur menyatakan hal tersebut bukanlah menjadi kendala eksternal dalam penyediaan aksesibilitas dan fasilitas bagi wisatawan penyandang disabilitas.

Dalam hal peraturan yang belum secara spesifik mengatur mengenai kebutuhan wisatawan penyandang disabilitas dan peraturan dan sanksi yang belum tegas untuk pengupayaan penyediaan aksesibilitas dan fasilitas bagi wisatawan penyandang disabilitas, pihak Monumen Bajra Sandhi dan Kawasan Pariwisata Sanur menyatakan bahwa peraturan sudah ada tetapi belum terlaksana secara maksimal. Lalu permintaan wisatawan penyandang disabilitas yang rendah, pihak Monumen Bajra Sandhi dan Kawasan Pariwisata Sanur juga menyatakan hal yang serupa bahwa rendahnya permintaan menjadi kendala dalam menyediakan aksesibilitas dan fasilitas bagi wisatawan penyandang disabilitas.

Peraturan yang belum secara spesifik mengatur mengenai kebutuhan wisatawan penyandang disabilitas dan peraturan dan sanksi yang belum tegas untuk pengupayaan penyediaan aksesibilitas dan fasilitas bagi wisatawan penyandang disabilitas hal tersebut menjadi kendala bagi Smailing Tour dan Bali Access Travel. Sedangakan permintaan wisatawan penyandang disabilitas yang rendah, hal tersebut menjadi kendala bagi pihak Smailing Tour tetapi tidak menjadi kendala bagi Bali Access Travel.

\section{PEMBAHASAN \\ Bentuk Penyediaan Aksesibilitas}

Bnetuk penyediaan akesibilitas terbagi menjadi 2 yaitu aksesibilitas fisik dan aksesibilitas non fisik. Aksesibilitas fisik dalam artikel ini yakni tersedianya pintu, tangga, dan lift khusus, tersedianya tempat parkir, tersedianya toilet, tersedianya telepon, tersedianya peringatan darurat, tersedianya rambu, tersedianya trotoar khusus penyandang disabilitas, tersedianya ram, dan tersedianya tempat duduk. Sedangkan aksesibilitas non fisik yaitu tersedianya informasi yang andal, tersedianya peraturan dan regulasi terhadap aktivitas berwisata penyandang disabilitas, tersedianya pelayanan khusus, dan tersedianya informasi.

\section{Aksesibilitas Fisik}

Dalam sudut pandang Dinas Pariwisata Kota Denpasar, objek- objek wisata di Kotamadya Denpasar Kecamatan Denpasar Selatan sampai saat ini belum tersedia aksesibilitas fisik seperti pintu geser, tangga, dan lift khusus. Hal ini dipengaruhi oleh arsitektur Bali yang menjunjung kearifan lokal sehingga lebih banyak menggunakan tangga 
dibandingkan lift, sehingga jarang ditemukan lift di objek-objek wisata di Kotamadya Denpasar khususnya objek wisata buatan. Observasi di salah satu pantai di Denpasar yaitu Pantai Karang, memang tersedia satu toilet khusus bagi wisatawan penyandang disabilitas, akan tetapi toilet tersebut tidak dapat digunakan karena pintu toilet terkunci dan tidak tersedia air. Sehingga wisatawan penyandang disabilitas tetap harus menggunakan toilet yang sama dengan orangorang pada umumnya.

HPI Bali, ASITA Bali, dan PHRI Bali sampai saat ini belum menyediakan aksesibilitas fisik bagi wisatawan penyandang disabilitas. Dalam Peraturan Menteri Pariwisata Dan Ekonomi Kreatif Republik Indonesia Nomor PM.53/HM.001/MPEK/2013 tentang Standar Usaha Hotel terdapat beberapa kriteria dalam standar usaha hotel baik kriteria mutlak maupun kriteria tidak mutlak. Pada kriteria tersebut dibagi menjadi tiga aspek yaitu produk, pelayanan, dan pengelolaan. Penyediaan aksesibilitas dan fasilitas fisik bagi wisatawan penyandang disabilitas disebutkan di dalam kriteria tidak mutlak pada aspek produk, yaitu memiliki ram bagi wisatawan penyandang disabilitas, toilet khusus wisatawan penyandang disabilitas, dan penyediaan kamar khusus bagi wisatawan penyandang disabilitas minimal 1 kamar dari 200 kamar yang tersedia. Hal tersebut diperkuat dengan pernyataan Bapak Purwa (Direktur Eksekutif PHRI Bali) yaitu:

“...kalo khusus untuk penyandang cacat itu diharapakan kalo mereka minimal memiliki 200 kamar diharapkan ada 1 fasilitas kamar penyandang cacat, jadi kalo yang kecil- kecil cuma 15 kamar atau 100 mereka belum disyaratkan..." (Wawancara di Gedung Bali Tourism Board pada 12 Desember 2017)

Aksesibilitas fisik yang tersedia di Villa $\mathrm{G}$ at Ellora, Bali One Care, dan Rumah Sanur adalah tersedianya pintu khusus yaitu pintu geser, ram, toilet khusus, rambu, dan tempat parkir khusus. Selain aksesibilitas fisik yang telah disebutkan Villa $G$ at Ellora dan Bali One Care mempunyai fasilitas lain seperti kursi roda, electric hoist, kolam renang dengan hoist, shower commode, dan shower chair, baby trolley, baby car seat, mobil semi hidrolik, dan sebagainya.
Pihak Monumen Bajra Sandhi menyatakan bahwa Monumen Bajra Sandhi idealnya diperuntukkan bagi wisatawan dengan fisik yang normal tetapi tidak dapat dipungkiri bahwa wisatawan penyandang disabilitas juga dapat berkunjung ke Monumen Bajra Sandhi. Monumen Bajra Sandhi merupakan bangunan yang memiliki banyak tangga, dan jika membangun lift pada Monumen Bajra Sandhi maka akan merubah konsep filosofis yang ada. Hal ini didukung oleh pernyataan Bapak Dewa (Divisi informasi pada Monumen Bajra Sandhi) yaitu:

“...Gak ada lift cuma gini konsepnya

semua mengandung filsafat, ada

filosofinya semua..." (Wawancara di

Monumen Bajra Sandhi pada 29

November 2017)

Pada sebagian besar pantai di Kawasan Pariwisata Sanur aksesibilitas fisik bagi wisatawan penyandang disabilitas belum tersedia. Tetapi trotoar pada pantai di Kawasan Pariwisata Sanur cukup mudah untuk dilalui oleh wisatawan dengan menggunakan kursi roda, dan jarak ketinggian trotoar dan bibir pantai tidak terlalu jauh sehingga mudah diakses oleh wisatawan dengan menggunakan kursi roda. Lain halnya dengan Pantai Karang, dimana pada pantai tersebut sudah tersedia satu toilet khusus bagi wisatawan penyandang disabilitas. Hanya saja toilet khusus bagi wisatawan penyandang disabilitas terkunci dan tidak dapat digunakan.

Smailing Tour dan Bali Access Travel sebagian besar belum menyediakan aksesibilitas bagi wisatawan penyandang disabilitas. Walaupun begitu pihak Smailing Tour berusaha untuk selalu menyediakan alat bantu jika ada permintaan dengan bekerja sama dengan pemasok yang alat bantu bagi wisatawan penyandang disabilitas yaitu Bali One Care. Sampai saat ini yang baru disediakan oleh Bali Access Travel adalah ram portabel. Diluar dari hal tersebut, Bali Access Travel memiliki satu unit mobil hidrolik dengan kapasitas hingga lima orang dengan berbagai kombinasi jumlah kursi dan wheelchair. Bali Access Travel juga memiliki paket khusus bagi wisatawan penyandang disabilitas serta menyediakan kursi roda, shower commode, shower chair, hoist dan ram portabel, tongkat jalan, dan sebagainya 


\section{Aksesibilitas Non Fisik}

Aktivitas berwisata orang- orang secara umum tidak hanya dititikberatkan pada penyediaan bentuk aksesibilitas fisik saja tetapi juga penyediaan aksesibilitas non fisik. Informasi yang andal yang dimaksud adalah penyediaan informasi dalam bentuk huruf Braile maupun bentuk audiovisual, dan informasi seperti itu belum disediakan oleh Dinas Pariwisata Kota Denpasar. Peraturan dan regulasi terhadap aktivitas berwisata penyandang disabilitas adalah UndangUndang Nomor 10 Tahun 2009 Tentang Kepariwisataan, Peraturan Menteri Pariwisata dan Ekonomi Kreatif Republik Indonesia Nomor PM.53/HM.001/MPEK/2013 tentang Standar Usaha Hotel, dan Peraturan Daerah Provinsi Bali Nomor 2 Tahun 2012 pasal 26 ayat $4 \mathrm{c}$ dan pasal 27 ayat $3 \mathrm{~d}$. Peraturan dan regulasi sudah tersedia oleh Dinas Pariwisata Kota Denpasar, hanya saja setelah dipastikan kembali dengan pihak industri pariwisata peraturan tersebut belum sepenuhnya terealisasi.

Aksesibilitas non fisik oleh masyarakat sebagian besar belum terpenuhi. HPI Bali, PHRI Bali, ASITA Bali menyatakan ketersediaan peraturan dan regulasi memang sudah tersedia dari pemerintah mengenai penyediaan aksesibilitas dan fasilitas bagi wisatawan penyandang disabilitas, tetapi dalam hal eksekusi dan realisasi belum dilakukan secara maksimal dan tidak spesifik. HPI Bali, PHRI Bali, ASITA Bali menyatakan hal yang serupa bahwa sampai sampai saat ini mereka belum memiliki standard operational procedure bagi sumber daya manusia dalam hal melayani wisatawan penyandang disabilitas. Standard operational procedure yang diberikan kepada pegawai atau karyawan hanya secara umum saja.

Bentuk aksesibilitas non fisik oleh Villa $\mathrm{G}$ at Ellora, Rumah Sanur, dan Bali One Care yakni informasi yang andal belum tersedia. Informasi yang andal sangat diperlukan bagi wisatawan penyandang disabilitas agar mereka dapat mengetahui informasi yang tepat tanpa perlu terjadi kesalahanpahaman. Mengenai pelayanan khusus yang disediakan oleh stakeholder, Villa $\mathrm{G}$ at Ellora dan Bali One Care bekerja sama dengan rumah sakit BIMC dalam penyediaan personal carer. Pemilihan kerja sama dengan BIMC Hospital dilakukan karena rata- rata perawat yang berasal dari
BIMC Hospital dapat berbahasa Inggris sehingga mudah untuk berkomunikasi. Sedangkan Rumah Sanur, Monumen Bajra Sandhi, dan Kawasan Pariwisata Sanur belum memiliki atau menyediakan pelayanan khusus bagi wisatawan penyandang disabilitas. Pelayanan hanya sebatas pelayanan secara umum saja, tetapi pelayanan yang diberikan dimaksimalkan agar kepuasan konsumen tetap dapat tercapai.

Penyediaan aksesibilitas non fisik bagi wisatawan penyandang disabilitas yaitu tersedianya informasi yang andal, tersedianya peraturan dan regulasi terhadap aktivitas berwisata penyandang disabilitas, dan tersedianya pelayanan khusus. Penyediaan informasi yang andal oleh pihak Smailing Tour dan Bali Access Travel belum tersedia. Hal tersebut memang diakui oleh pihak Smailing Tour dan Bali Access Travel dan sesuai dengan observasi yang dilakuka, dimana website dan brosur kedua travel tersebut belum tersedia dengan huruf Braile maupun bentuk audiovisual. Mengenai peraturan dan regulasi, Smailing Tour dalam mengakui tidak tahu- menahu soal peraturan dan regulasi terhadap aktivitas berwisata penyandang disabilitas, dan menurut Bali Access Travel bahwa peraturan yang sudah ada belum seratus persen dijalankan oleh industri- industri pariwisata. Smailing Tour belum menyediakan pelayanan khusus kepada wisatawan penyandang disabilitas sedangkan Bali Access Travel dalam penyediaan pelayanan khusus bagi wisatawan penyandang disabilitas bekerja sama dengan BIMC Hospital dalam penyediaan personal carer.

\section{Kendala Penyediaan Aksesibilitas}

Kendala adalah faktor, keadaan dan segala hal yang membatasi, menghalangi, dan mencegah stakeholder yaitu pemerintah, masyarakat (lembaga), dan industri pariwisata. Kendala internal dalam hal ini adalah modal atau anggaran yang terbatas dan sumber daya manusia yang belum kapabel dalam menangani wisatawan penyandang disabilitas. Sedangkan kendala eksternal yaitu peraturan yang belum secara spesifik mengatur mengenai kebutuhan wisatawan penyandang disabilitas, permintaan yang rendah, dan peraturan yang belum tegas untuk pengupayaan penyediaan fasilitas bagi penyadang disabilitas. 


\section{Kendala Internal}

Kendala internal bagi Dinas Pariwisata Kota Denpasar dalam penyediaan aksesibilitas bagi wisatawan penyandang disabilitas adalah sumber daya manusia yang belum kapabel dalam menangani wisatawan penyandang disabilitas. Sumber daya manusia yang kapabel dalam menangani wisatawan penyandang disabilitas merupakan aspek penting dalam memberikan kepuasan kepada wisatawan penyandang disabilitas, hanya saja sampai saat ini masih jarang sekali sumber daya manusia di industri pariwisata yang memiliki kemampuan dalam menangani penyandang disabilitas.

Penyediaan aksesibilitas dan fasilitas bagi wisatawan penyandang disabilitas biasanya akan memakan anggaran lebih banyak daripada aksesibilitas dan fasilitas bagi wisatawan pada umumnya. Tetapi menurut HPI Bali, ASITA Bali, dan PHRI Bali modal yang terbatas bukanlah sebuah kendala internal dalam penyediaan aksesibilitas bagi wisatawan penyandang disabilitas. Hal ini diperkuat dengan pernyataan Pak Purwa (Direktur Eksekutif PHRI Bali) yaitu:

“...oh ndak kalo itu kan kecil ya

kalaupun mereka harus ada itu katakan dari 200 kamar hanya menyediakan untuk 1 kamar itu buat mereka (hotel) ndak masalah..."

(Wawancara di Gedung Bali Tourism

Board pada 12 Desember 2017)

ASITA Bali menyatakan bahwa sumber manusia yang belum kapabel akan menjadi kendala dalam berkomunikasi dengan wisatawan penyandang disabilitas sehingga kepuasan wisatawan penyandang disabilitas tidak dapat terpenuhi secara sempurna dan akan mengakibatkan kesalahpahaman. Walaupun HPI Bali dan PHRI Bali tidak merasa bahwa sumber manusia yang belum kapabel menjadi kendala yang berarti.

Modal dan anggaran yang terbatas menjadi kendala bagi Villa $G$ at Ellora, Bali One Care dan Rumah Sanur karena fasilitas dan alat bantu cukup mahal dan biaya perawatan yang harus rutin dilakukan. Alat bantu bagi penyandang disabilitas cukup mahal dan di Indonesia sangat jarang ditemukan pabrik alat bantu penyandang disabilitas yang sesuai dengan standar internasional. Selain itu alat- alat bantu khusus penyandang disabilitas di produksi di luar negeri dan di rebranding di Indonesia sehingga harganya melonjak tinggi. Akan tetapi sumber daya manusia yang belum kapabel tidak menjadi kendala internal karena Villa $G$ at Ellora dan Bali One Care bekerja sama dengan BIMC Hospital dalam penyediaan personal carer dan sudah sangat professional dalam menangani wisatawan penyandang disabilitas. Sedangkan Rumah Sanur dapat memberikan pelayanan kepada penyandang disabilitas akan dilaksanakan dan dilakukan secara bertahap.

Kendala internal yang diahdapi oleh Monumen Bajra Sandhi dan Kawasan Pariwisata Sanur dalam penyediaan aksesibilitas bagi wisatawan penyandang disabilitas adalah modal atau anggaran yang terbatas. Menurut Monumen Bajra Sandhi hal tersebut disebabkan karena pengajuan anggaran harus diajukan melalui pemerintah terlebih dahulu dan akan memakan waktu yang lama. Sedangkan Kawasan Pariwisata Sanur yang diwakili oleh Yayasan Pembangunan Sanur, modal yang terbatas menjadi kendala karena aksesibilitas dan fasilitas bagi wisatawan penyandang disabilitas lebih banyak dan lebih kompleks sehingga akan memakan modal yang cukup besar dalam penyediaanya. Lalu mengenai sumber daya manusia memang menjadi kendala karena sumber daya manusia di Monumen Bajra Sandhi belum bisa berbahasa Isyarat ataupun menggunakan huruf Braile, dan harus melakukan pelatihan lagi yang akan memakan waktu lama. Hal tersebut juga sama disampaikan oleh Yayasan Pembangunan Sanur, dimana sumber daya belum kapabel dalam menangani wisatawan penyandang disabilitas menjadi kendala karena pola pikir industri pariwisata di kawasan Sanur masih belum terbentuk untuk menyediakan aksesibilitas bagi wisatawan penyandang disabilitas.

Bagi Bali Access Travel modal merupakan suatu kendala karena fasilitas dan alat bantu yang disediakan lebih banyak dibandingkan dengan fasilitas bagi wisatawan pada umumnya sehingga harus memiliki modal yang cukup besar. Bagi Smailing Tour modal atau anggaran tidak menjadi sebuah kendala karena jika ada permintaan khusus dari tamu maka tamu tersebut akan dikenakan biaya tambahan. Sumber daya manusia tidak menjadi kendala bagi Bali Access Travel 
karena Bali Access Travel bekerja sama dengan BIMC Hospital dalam penyediaan personal carer. Sedangkan bagi Smailing Tour sumber daya manusia seperti pramuwisata, pegawai, atau karyawan dapat dilakukan pelatihan sehingga hal tersebut bukanlah menjadi kendala yang berarti.

\section{Kendala Eksternal}

Menurut Dinas Pariwisata Kota Denpasar peraturan sudah ada yang mengatur mengenai kebutuhan wisatawan penyandang disabilitas, hanya saja observasi yang dilakukan di lapangan, peraturan tersebut belum dieksekusi dan terealisasi. Peraturan yang belum secara spesifik mengatur mengenai kebutuhan wisatawan penyandang disabilitas dialami oleh pihak HPI dan ASITA, sedangkan PHRI sudah mempunyai regulasi yang tertulis pada Peraturan Menteri Pariwisata dan Ekonomi Kreatif tahun 2013 tentang Standar Usaha Hotel. Kendala eksternal yang dihadapi oleh hotel dan restoran menurut PHRI yang diwakili oleh Bapak Purwa adalah karena hotel dan restoran belum mendapatkan komplain atau keluhan untuk masalah aksesibilitas dan fasilitas penyandang disabilitas, kontrol regulasi juga belum ketat oleh pemerintah. Selain itu hal aksesibilitas dan fasilitas belum menjadi tuntutan dari pihak agent sehingga pihak hotel dan restoran juga tidak menyediakan fasilitas dan aksesibilitas khusus. Lalu pada indikator permintaan wisatawan penyandang disabilitas yang rendah dan peraturan dan sanksi yang belum tegas untuk pengupayaan penyediaan aksesibilitas dan fasilitas bagi wisatawan penyandang disabilitas, HPI, PHRI, dan ASITA menyatakan hal yang serupa bahwa hal terebut menjadi kendala yang mereka hadapi.

Bali One Care, Villa G at Ellora, dan Rumah Sanur menilai bahwa yang menjadi kendala eksternal adalah peraturan yang belum secara spesifik mengatur mengenai kebutuhan wisatawan penyandang disabilitas dan peraturan dan sanksi yang belum tegas untuk pengupayaan penyediaan aksesibilitas bagi wisatawan penyandang disabilitas hanya saja walaupun sudah ada regulasi dan undangundang mengenai penyediaan fasilitas dan aksesibilitas bagi wisatawan penyandang disabilitas tetapi tidak ada tindak lanjut dari pemerintah atau pun monitoring dari pemerintah. Sehingga industri yang memiliki pasar wisatawan berkebutuhan khusus kesulitan dalam menyediakan kebutuhan dan produk bagi wisatawan penyandang disabilitas. Minimnya fasilitas dan aksesibilitas yang disediakan oleh pemerintah bagi wisatawan penyandang disabilitas menyebabkan industri pariwisata tidak berani menjual atau menawarkan produk bagi wisatawan penyandang disabilitas. Hal ini dapat dibuktikan oleh pernyataan Pak Romi (Bali One Care) yaitu:

"...karena itu sangat berhubungan once and another jadi fasilitas tidak ada travel agent juga tidak akan berani memasarkan kemudian tamu atau klien juga tidak akan mau dateng jadi kalo tamu juga tidak mau dateng ya bisnis tidak akan bisa running... semua saling berhubungan seperti itu. Kalo titik poin sih menurut saya sebenernya ada di pemerintah..." (Wawancara di Kantor Bali One Care pada 27 Oktober 2017)

Sedangkan permintaan wisatawan penyandang disabilitas tidak menjadi kendala yang besar bagi Bali One Care, Villa $G$ at Ellora, dan Rumah Sanur karena penyandang disabilitas sudah menjadi segmen pasar bagi mereka.

Monumen Bajra Sandhi dan Kawasan Pariwisata Sanur menyatakan bahwa peraturan yang belum secara spesifik mengatur mengenai kebutuhan wisatawan penyandang disabilitas, permintaan wisatawan penyandang disabilitas yang masih rendah, dan peraturan dan sanksi yang belum tegas untuk pengupayaan penyediaan aksesibilitas bagi wisatawan penyandang disabilitas adalah kendala. Karena tidak ada tekanan dari pihak pemerintah sehingga penyediaan aksesibilitas bagi wisatawan penyandang disabilitas tidak akan menjadi prioritas bagi industri pariwisata. Pihak Monumen Bajra Sandhi dan Kawasan Pariwisata Sanur membenarkan bahwa permintaan wisatawan penyandang disabilitas yang masih rendah dibandingkan dengan wisatawan pada umumnya, karena inisiatif untuk menyediakan aksesibilitas dan fasilitas bagi wisatawan penyandang disabilitas belum terbentuk.

Smailing Tour dan Bali Access Travel menyatakan bahwa peraturan yang belum secara spesifik mengatur mengenai kebutuhan wisatawan penyandang disabilitas dan peraturan dan sanksi yang belum tegas untuk 
pengupayaan penyediaan aksesibilitas bagi wisatawan penyandang disabilitas menjadi kendala bagi Smailing Tour dan Bali Access Travel sehingga pasar bagi wisatawan penyandang disabilitas walaupun sudah ada tetapi belum kuat. Sedangkan permintaan yang masih rendah menjadi kendala bagi Smailing Tour sehingga target pasar Smailing Tour tidak mengarah kepada wisatawan penyandang disabilitas. bagi Bali Access Travel, permintaan yang masih rendah tidak menjadi kendala karena segmen pasar Bali Access Travel adalah wisatawan berkebutuhan khusus.

\section{SIMPULAN DAN SARAN Simpulan}

Kotamadya Denpasar Kecamatan Denpasar Selatan sebagai daerah wisata belum siap dan belum ramah dalam penyediaan aksesibilitas bagi wisatawan penyandang disabilitas, karena aksesibilitas baik fisik maupun non fisik yang belum masih sangat minim bagi wisatawan penyandang disabilitas. Minimnya aksesibilitas bagi wisatawan penyandang disabilitas mengakibatkan mereka kesulitan dalam berwisata di Kotamadya Denpasar Kecamatan Denpasar Selatan dan akhirnya wisatawan penyandang disabilitas lebih banyak berdiam diri di akomodasi saja.

Penyediaan aksesibilitas bagi wisatawan penyandang disabilitas oleh stakeholder di Kotamadya Denpasar khususnya Kecamatan Denpasar Selatan terbagi menjadi aksesibilitas fisik dan aksesibilitas non fisik. Bentuk aksesibilitas fisik bagi wisatawan penyandang disabilitas oleh stakeholder di Kotamadya Denpasar khususnya Kecamatan Denpasar Selatan yaitu berupa ram dan pintu khusus (geser). Sedangkan bentuk aksesibilitas non fisik bagi wisatawan penyandang disabilitas oleh stakeholder di Kotamadya Denpasar khususnya Kecamatan Denpasar Selatan yaitu berupa peraturan dan regulasi terhadap aktivitas berwisata penyandang disabilitas dan tersedianya pelayanan khusus (SDM yang kapabel dalam melayani penyandang disabilitas).

Kendala yang dihadapi oleh stakeholder pariwisata dalam penyediaan aksesibilitas bagi wisatawan penyandang disabilitas di Kotamadya Denpasar khususnya Kecamatan Denpasar Selatan terbagi menjadi dua yakni kendala internal dan kendala eksternal.
Kendala internal yang dihadapi oleh stakeholder pariwisata dalam penyediaan aksesibilitas bagi wisatawan penyandang disabilitas di Kotamadya Denpasar Kecamatan Denpasar Selatan adalah modal yang terbatas. Sedangkan kendala eksternal yang dihadapi oleh stakeholder pariwisata dalam penyediaan aksesibilitas bagi wisatawan penyandang disabilitas di Kotamadya Denpasar Kecamatan Denpasar Selatan yakni peraturan yang belum secara spesifik mengatur mengenai kebutuhan wisatawan penyandang disabilitas serta sanksi yang belum tegas untuk pengupayaan penyediaan aksesibilitas dan fasilitas bagi wisatawan penyadang disabilitas.

\section{Saran}

Anjuran bagi stakeholder di Kotamadaya Denpasar Kecamatan Denpasar Selatan dalam menyediakan aksesibilitas bagi wisatawan penyandang disabilitas yakni,

1. Pemerintah sebaiknya membuat kerangka hukum yang spesifik dalam hal penyediaan aksesibilitas bagi wisatawan penyandang disabilitas baik fisik maupun non fisik agar penyediaan aksesibilitas bagi wisatawan penyandang disabilitas dapat terpenuhi.

2. Stakeholder sebaiknya berinisiatif dalam menyediakan aksesibilitas bagi wisatawan penyandang disabilitas.

3. Memperbaiki koordinasi antar stakeholder dalam penyediaan aksesibilitas bagi wisatawan penyandang disabilitas.

4. Melatih sumber daya manusia pada stakeholder pariwisata dalam melayani wisatawan penyandang disabilitas.

5. Memberikan informasi yang lengkap dan andal sehingga wisatawan penyandang disabilitas dapat dengan mudah mendapatkan informasi yang akurat di lokasi wisata.

6. Merubah pola pikir stakeholder pariwisata bahwa penyediaan aksesibilitas bagi wisatawan penyandang disabilitas adalah hal yang juga penting untuk disediakan. 


\section{Kepustakaan}

Anonim. (2011). Undang Undang Nomor 19. Tentang Pengesahan Hal- Hal Penyandang Disabilitas. Jakarta.

(2009). Undang Undang Nomor 10 . Tentang Kepariwisataan. Jakarta.

. (2013). Peraturam Menteri Pariwisata dan Ekonomi Kreatif Nomor. 53. Tentang Standar Usaha Hotel. Jakarta.

(2012). Peraturan Daerah Provinsi Bali Nomor. 2. Tentang Kepariwisataan Budaya Bali. Bali.

(1998). Peraturan Pemerintah Nomor 43.

Tentang Upaya Peningkatan

Kesejahteraan Sosial Penyandang Cacat. Jakarta.

(2015). Accessible Tourism fo All: An Opportunity within Our Reach. UNWTO.

. (2015). Manual on Accessible Tourism for All - Public-private Partnerships and Good Practices. Madrid: UNWTO ; Fundación ACS.

(2016). Tourism for All - Promoting Universal Accessibility" Good Practices in the Accessible Tourism Supply Chain. Madrid: UNWTO.

Pitana, I. Gde dan Gayatri, Putu G. 2005. Sosiologi Pariwisata.

http://ethics.unwto.org/en/content/global-codeethics-tourism-article-7 diunduh pada 5 Maret 2017 pukul 2.23

surveymeter.org/site/download_research/59

diunduh pada 19 Januari 2018 pukul 19.36 